www.jmscr.igmpublication.org

Impact Factor 5.84

Index Copernicus Value: 71.58

ISSN (e)-2347-176x ISSN (p) 2455-0450

crossref DOI: _https://dx.doi.org/10.18535/jmscr/v5i10.121

Journal Of Medical Science And Clinical Research

\title{
A Comparative Study Between Two Communities \& Regional Variation in level of MDA with respect to Waist Hip Ratio and BMI in Response to an Exclusive Fibre Diet
}

\author{
Authors \\ Nita Sahi ${ }^{1}$, Shubham Jain ${ }^{2}$, Nidhi Ranawat ${ }^{3}$ \\ ${ }^{1}$ Assistant Professor Department of Biochemistry PMCH Udaipur \\ ${ }^{2,3}$ PG Student Department of Biochemistry PMCH Udaipur \\ Email: Shubhamjain094@gmail.com
}

\begin{abstract}
Obesity is a condition where a person has accumulated so much body fat that it might have a negative effect on their health. Body mass index is a statistical measurement derived from height \& weight BMI between 18.5 \& $25 \mathrm{~kg} / \mathrm{m}^{2}$ indicate a normal weight. BMI of 25-29.9 is considered over weight\& that of 30 $\mathrm{kg} / \mathrm{m}^{2}$ or above is considered obese. High BMI now ranks with major global health problems like high cholesterol, high blood pressure, in total global burden of disease. For people with obesity, weight loss based solely on life style change in very challenging ${ }^{[2,3]}$ oxidative stress is essential an imbalance between the production of free radicals \& obesity of the body to counteract or detoxify their harmful effects through neutralization by antioxidant. Present study was carried out on 1000 subjects 650 were Rajasthani \& 350 were south Indian. We divided them further according to BMI and obesity indices. They were than estimated for MDA before consuming fibres diet.MDA was also estimated after 30 days consumption and results were statistically evaluated. [6] BMI \& various other indices of obese like waist circumference, hip circumference, waist hip ratio are considered as screening tools for overweight \& obese. Oxidative stress increased with increased BMI. Dietary effect showed significant drop in all three categories of BMI $(P<0.001)$.
\end{abstract}

Keywords: MDA, WHR, BMI, Fibre, Obesity.

\section{Introduction}

According to CDC on estimate 112000 excess deaths per year are associated with obesity. Obesity puts individuals at risk for more than 30 chronic health conditions like type 2 diabetes, hypertension, stress incontinence, heart failure. Free radicals generate lipid peroxidation process in an organism Malondialdehyde is one of the products of poly unsaturated fatty acids peroxide in cells. Increased free radicals peroxidation causes over production of MDA level which is a marker of oxidative stress\& antioxidant status in obese people ${ }^{[10]}$. Present study was carried out on 1000 subjects 650 were Rajasthani \& 350 were south Indian we divided them further according to BMI and obesity indices. They were then estimated for MDA before consuming fibres diet which included fruits like prunes, pear apple, raspberries, legumes like navy beans, cooked black beans, cooked kidney beans, canned baked 
beans, beads like rye, gram flakes, nuts like almonds, peanuts, walnuts, pecans, pistachio, cooked lime beans, split peas, pumpkin, tomato, broccoli in their diet which are fibres rich food with no inclusion of fat and other ingredients. MDA was also estimated after 30 days consumption and results were statistically evaluated. ${ }^{[3]}$ BMI \&various other indices of obese like waist circumference, hip circumference, waist hip ratio are considered as screening tools for overweight \& obese. Our study lays stress on anthropometric correlation with fibre food in 1000 subjects aged 18-50 year coming from Rajasthan and south India. We classified the study in 2 parts. In first part of our study groups were made according to various indices of overweight status. In the second part of our study MDA was estimated to find out the effect of an exclusive fibres diet on this oxidative stress marker.

Normal weight subjects had a normal MDA but after consuming exclusive fibre food for 30 days, MDA dropped $(\mathrm{P}<0.001)$ in both the communities. After comparing both region group, according to indices more significant drop was observed for overweight subjects. Subjects with high indices had high oxidative stress.

MDA estimated for obese group was $2.98 \pm 0.16 \mathrm{n}$ moles $/ \mathrm{ml} \mathrm{v/s} 1.60 \pm 0.30 \mathrm{nmoles} / \mathrm{ml}$ for normal group. The dietary effects exhibited high significance in all category of indices $(\mathrm{P}<0.001)$. Body fat percentage of less than $30 \%$ and more than $30 \%$ was considered and total body fat of less than $20 \mathrm{~kg} \&$ more than $20 \mathrm{~kg}$ was taken into account to show correlation of the parameters of oxidative stress\& dietary effect was approximately equal for each category.

\section{Material and Method}

Present work was done in the department of Biochemistry in Pacific Dental College. Normal subject of same age with that of respective over weight group was taken as controls. Thiobarbituric acid reactive substance (TBARS) ${ }^{1}$

\section{Procedure}

To $0.8 \mathrm{ml}$ serum, $0.2 \mathrm{ml}$ of TCA-TBA $\mathrm{HCl}$ reagent was added, mixed and kept in boiling water bath for 10 minutes. After cooling, $2 \mathrm{ml}$ of freshly prepared $\mathrm{NaOH}$ solution was added. The pink colour was obtained and absorbance was measured at $535 \mathrm{~nm}$ against blank which had distilled water in place of serum.

\section{Calculation}

Molar extinction of TBARS at $535 \mathrm{~nm} \mathrm{1.56X} \mathrm{10-}$ $5 / \mathrm{M} / \mathrm{Cm}$

$\frac{\mathrm{V} x \Delta \mathrm{OD} \text { at } 535 \mathrm{~nm}}{0.156}=\frac{\mathrm{Vx} \Delta \mathrm{OD} \text { at } 535 \mathrm{~nm}}{0.156}$

$=25.6 \times \Delta \mathrm{OD}$ at $535 \mathrm{n}$ moles $/ \mathrm{serum}$

Normal range $=2.0-3.0 \mathrm{n}$ mole $/ \mathrm{ml}$ serum

\section{Statistical analysis}

1. Mean $(X)=\quad$ Sum of observations

Total No. of cases

2. Standard Deviation (S.D)

$=\underline{\sqrt{ } \text { Sum }+ \text { square of term- }(\text { mean }) 2}$

n-1

$\mathrm{n}=$ number of obs.

3. Students " $t$ " test:

SED

$$
\mathrm{t}=\underline{\text { Mean 1-Mean } 2}
$$

4. $\mathrm{SED}=\sqrt{ }((\mathrm{SE} 1 \times \mathrm{SE} 1)+(\mathrm{SE} 2 \times \mathrm{SE} 2)$

\section{Results}

ICMR suggest normal range of MDA as 1.05-3.2 $\mathrm{n}$ moles/ml of serum. In our study MDA in total subject before consumption of fibrous food was $2.35 \pm 0.76$ which improved to $1.8 \pm 0.46$ after consumption $(\mathrm{P}<0.001)$.

Result are tabulated in Rajasthan\& south Indian subjects in tables $(\mathrm{a} \& \mathrm{~b}) \&$ tables $2(\mathrm{a} \& \mathrm{~b})$ 
Table 1(A)

\begin{tabular}{|c|c|c|c|c|c|c|c|c|c|c|c|c|}
\hline \multirow[b]{3}{*}{ Parameters } & \multicolumn{4}{|c|}{$\begin{array}{c}\text { Total } \\
(\mathrm{n}=1000)\end{array}$} & \multicolumn{4}{|c|}{$\begin{array}{c}\text { Rajasthani } \\
(\mathrm{n}=650 / 1000)\end{array}$} & \multicolumn{4}{|c|}{$\begin{array}{c}\text { South Indians } \\
(\mathrm{n}=350 / 1000)\end{array}$} \\
\hline & \multicolumn{2}{|c|}{ Before } & \multicolumn{2}{|c|}{ After } & \multicolumn{2}{|c|}{ Before } & \multicolumn{2}{|c|}{ After } & \multicolumn{2}{|c|}{ Before } & \multicolumn{2}{|c|}{ After } \\
\hline & Mean & $\pm \mathrm{SD}$ & Mean & \pm SD & Mean & $\pm \mathrm{SD}$ & Mean & $\pm \mathrm{SD}$ & Mean & $\pm \mathrm{SD}$ & Mean & $\pm \mathrm{SD}$ \\
\hline $\begin{array}{l}\text { Malondialdehyde } \\
(\mathrm{nmol} / \mathrm{ml})\end{array}$ & 2.35 & 0.76 & 1.8 & 0.46 & 2.33 & 0.77 & 1.81 & 0.48 & 2.37 & 0.76 & 1.79 & 0.44 \\
\hline \multirow[b]{3}{*}{ WT range $50-75$} & \multicolumn{4}{|c|}{$\begin{array}{c}\text { Total } \\
(\mathrm{n}=260 / 1000)\end{array}$} & \multicolumn{4}{|c|}{$\begin{array}{l}\text { Rajasthani } \\
(n=136 / 260)\end{array}$} & \multicolumn{4}{|c|}{$\begin{array}{l}\text { South Indians } \\
(\mathrm{n}=124 / 260)\end{array}$} \\
\hline & \multicolumn{2}{|c|}{ Before } & \multicolumn{2}{|c|}{ After } & \multicolumn{2}{|c|}{ Before } & \multicolumn{2}{|c|}{ After } & \multicolumn{2}{|c|}{ Before } & \multicolumn{2}{|c|}{ After } \\
\hline & Mean & $\pm \mathrm{SD}$ & Mean & $\pm \mathrm{SD}$ & Mean & $\pm \mathrm{SD}$ & Mean & $\pm \mathrm{SD}$ & Mean & $\pm \mathrm{SD}$ & Mean & $\pm \mathrm{SD}$ \\
\hline $\begin{array}{l}\text { Malondialdehyde } \\
\text { (nmol/ml) }\end{array}$ & 3.16 & 0.28 & 2.24 & 0.18 & s3.18 & 0.28 & 2.27 & 0.19 & 3.15 & 0.28 & 2.21 & 0.16 \\
\hline \multirow[b]{3}{*}{$\mathrm{BMI}<18.5$} & \multicolumn{4}{|c|}{$\begin{array}{c}\text { Total } \\
(\mathrm{n}=43 / 1000) \\
\end{array}$} & \multicolumn{4}{|c|}{$\begin{array}{l}\text { Rajasthani } \\
(n=24 / 43)\end{array}$} & \multicolumn{4}{|c|}{$\begin{array}{l}\text { South Indians } \\
(\mathrm{n}=19 / 43)\end{array}$} \\
\hline & \multicolumn{2}{|c|}{ Before } & \multicolumn{2}{|c|}{ After } & \multicolumn{2}{|c|}{ Before } & \multicolumn{2}{|c|}{ After } & \multicolumn{2}{|c|}{ Before } & \multicolumn{2}{|c|}{ After } \\
\hline & Mean & $\pm \mathrm{SD}$ & Mean & $\pm \mathrm{SD}$ & Mean & $\pm \mathrm{SD}$ & Mean & $\pm \mathrm{SD}$ & Mean & $\pm \mathrm{SD}$ & Mean & $\pm \mathrm{SD}$ \\
\hline $\begin{array}{l}\text { Malondialdehyde } \\
(\mathrm{nmol} / \mathrm{ml})\end{array}$ & 1.17 & 0.17 & 0.96 & 0.13 & 1.19 & 0.23 & 0.97 & 0.17 & 1.15 & 0.05 & 0.95 & 0.05 \\
\hline \multirow[b]{3}{*}{ BMI 18.5-24.9 } & & $\begin{array}{r}\text { To } \\
(\mathrm{n}=526 \\
\end{array}$ & $\begin{array}{l}\text { al } \\
1000) \\
\end{array}$ & & & $\begin{array}{r}\text { Raja: } \\
(\mathrm{n}=28\end{array}$ & $\begin{array}{l}\text { hani } \\
1 / 526) \\
\end{array}$ & & & $\begin{array}{l}\text { Sout } \\
(\mathrm{n}=2\end{array}$ & $\begin{array}{l}\text { Indians } \\
46 / 526) \\
\end{array}$ & \\
\hline & Bef & & Af & & Bef & & $\mathrm{Af}$ & & Bet & & & \\
\hline & Mean & $\pm \mathrm{SD}$ & Mean & $\pm \mathrm{SD}$ & Mean & $\pm \mathrm{SD}$ & Mean & $\pm \mathrm{SD}$ & Mean & $\pm \mathrm{SD}$ & Mean & $\pm \mathrm{SD}$ \\
\hline $\begin{array}{l}\text { Malondialdehyde } \\
(\mathrm{nmol} / \mathrm{ml})\end{array}$ & 1.81 & 0.39 & 1.52 & 0.29 & 1.8 & 0.41 & 1.52 & 0.3 & 1.81 & 0.38 & 1.51 & 0.28 \\
\hline & & $\begin{array}{r}\text { To } \\
(\mathrm{n}=408 \\
\end{array}$ & $000)$ & & & $\begin{array}{r}\text { Raja } \\
(\mathrm{n}=21 \\
\end{array}$ & $\begin{array}{l}\text { hani } \\
408) \\
\end{array}$ & & & $\begin{array}{l}\text { Sou } \\
(\mathrm{n}=\end{array}$ & $\begin{array}{l}\text { Indians } \\
96 / 408) \\
\end{array}$ & \\
\hline & Bef & & $\mathrm{Af}$ & & Bef & & $\mathrm{Af}$ & & $\mathrm{Be}$ & & & \\
\hline BMI25-29.9 & Mean & $\pm \mathrm{SD}$ & Mean & $\pm \mathrm{SD}$ & Mean & $\pm \mathrm{SD}$ & Mean & $\pm \mathrm{SD}$ & Mean & $\pm \mathrm{SD}$ & Mean & $\pm \mathrm{SD}$ \\
\hline $\begin{array}{l}\text { Malondialdehyde } \\
(\mathrm{nmol} / \mathrm{ml})\end{array}$ & 3.1 & 0.2 & 2.22 & 0.16 & 3.1 & 0.2 & 2.26 & 0.15 & 3.11 & 0.19 & 2.17 & 0.16 \\
\hline & & $\begin{array}{r}\text { To } \\
(\mathrm{n}=24 \\
\end{array}$ & $000)$ & & & $\begin{array}{l}\text { Raja: } \\
(\mathrm{n}=1\end{array}$ & $\begin{array}{l}\text { hani } \\
\text { /24) } \\
\end{array}$ & & & Sou & $\begin{array}{l}\text { Indians } \\
10 / 24)\end{array}$ & \\
\hline & Bef & ore & Af & & Bef & & $\mathrm{Af}$ & & $\mathrm{Be}$ & & & \\
\hline BMI30-34.99 & Mean & $\pm \mathrm{SD}$ & Mean & $\pm \mathrm{SD}$ & Mean & $\pm \mathrm{SD}$ & Mean & $\pm \mathrm{SD}$ & Mean & \pm SD & Mean & $\pm \mathrm{SD}$ \\
\hline
\end{tabular}

Table 2 (A)

\begin{tabular}{|c|c|c|c|c|c|c|c|c|c|c|c|c|}
\hline \multirow[b]{3}{*}{ high WC,WHR and BMI >25 } & \multicolumn{4}{|c|}{$\begin{array}{c}\text { Total } \\
(\mathrm{n}=240 / 1000)\end{array}$} & \multicolumn{4}{|c|}{$\begin{array}{c}\text { Rajasthani } \\
(\mathrm{n}=131 / 240)\end{array}$} & \multicolumn{4}{|c|}{$\begin{array}{c}\text { South Indians } \\
(\mathrm{n}=109 / 240)\end{array}$} \\
\hline & \multicolumn{2}{|c|}{ Before } & \multicolumn{2}{|c|}{ After } & \multicolumn{2}{|c|}{ Before } & \multicolumn{2}{|c|}{ After } & \multicolumn{2}{|c|}{ Before } & \multicolumn{2}{|c|}{ After } \\
\hline & Mean & $\begin{array}{c} \pm \\
\mathrm{SD} \\
\end{array}$ & Mean & $\pm \mathrm{SD}$ & Mean & $\begin{array}{c} \pm \\
\mathrm{SD} \\
\end{array}$ & Mean & $\pm \mathrm{SD}$ & Mean & $\begin{array}{c} \pm \\
\mathrm{SD} \\
\end{array}$ & Mean & $\pm \mathrm{SD}$ \\
\hline \multirow[t]{4}{*}{ Malondialdehyde $(\mathrm{nmol} / \mathrm{ml})$} & 3.22 & 0.18 & 2.27 & 0.15 & 3.2 & 0.21 & 2.28 & 0.17 & 3.24 & 0.13 & 2.25 & 0.13 \\
\hline & \multicolumn{4}{|c|}{ Total $_{447 / 1000)}(\mathrm{n}=$} & \multicolumn{4}{|c|}{$\begin{array}{c}\text { Rajasthani } \\
(\mathrm{n}=239 / 447)\end{array}$} & \multicolumn{4}{|c|}{$\begin{array}{l}\text { South Indians } \\
(\mathrm{n}=208 / 447)\end{array}$} \\
\hline & \multicolumn{2}{|c|}{ Before } & \multicolumn{2}{|c|}{ After } & \multicolumn{2}{|c|}{ Before } & \multicolumn{2}{|c|}{ After } & \multicolumn{2}{|c|}{ Before } & \multicolumn{2}{|c|}{ After } \\
\hline & Mean & $\begin{array}{c} \pm \\
\text { SD } \\
\end{array}$ & Mean & $\pm \mathrm{SD}$ & Mean & $\begin{array}{l} \pm \\
\mathrm{SD}\end{array}$ & Mean & $\pm \mathrm{SD}$ & Mean & $\begin{array}{l} \pm \\
\text { SD }\end{array}$ & Mean & $\pm \mathrm{SD}$ \\
\hline Malondialdehyde (nmol/ml) & 1.64 & 0.35 & 1.4 & 0.28 & 1.62 & 0.35 & 1.39 & 0.28 & 1.66 & 0.35 & 1.4 & 0.27 \\
\hline \multirow[b]{3}{*}{$\begin{array}{l}\text { without correlation to any obesity } \\
\text { indices }\end{array}$} & \multicolumn{4}{|c|}{$\begin{array}{l}\text { Total } \\
n=314 / 1000)\end{array}$} & \multicolumn{4}{|c|}{$\begin{array}{c}\text { Rajasthani } \\
(\mathrm{n}=156 / 314)\end{array}$} & \multicolumn{4}{|c|}{$\begin{array}{l}\text { South Indians } \\
(\mathrm{n}=158 / 314)\end{array}$} \\
\hline & \multicolumn{2}{|c|}{ Before } & \multicolumn{2}{|c|}{ After } & \multicolumn{2}{|c|}{ Before } & \multicolumn{2}{|c|}{ After } & \multicolumn{2}{|c|}{ Before } & \multicolumn{2}{|c|}{ After } \\
\hline & Mean & $\begin{array}{c} \pm \\
\text { SD }\end{array}$ & Mean & $\pm \mathrm{SD}$ & Mean & $\begin{array}{c} \pm \\
\mathrm{SD}\end{array}$ & Mean & $\pm \mathrm{SD}$ & Mean & $\begin{array}{c} \pm \\
\text { SD }\end{array}$ & Mean & $\pm \mathrm{SD}$ \\
\hline
\end{tabular}


Table 2 (B).

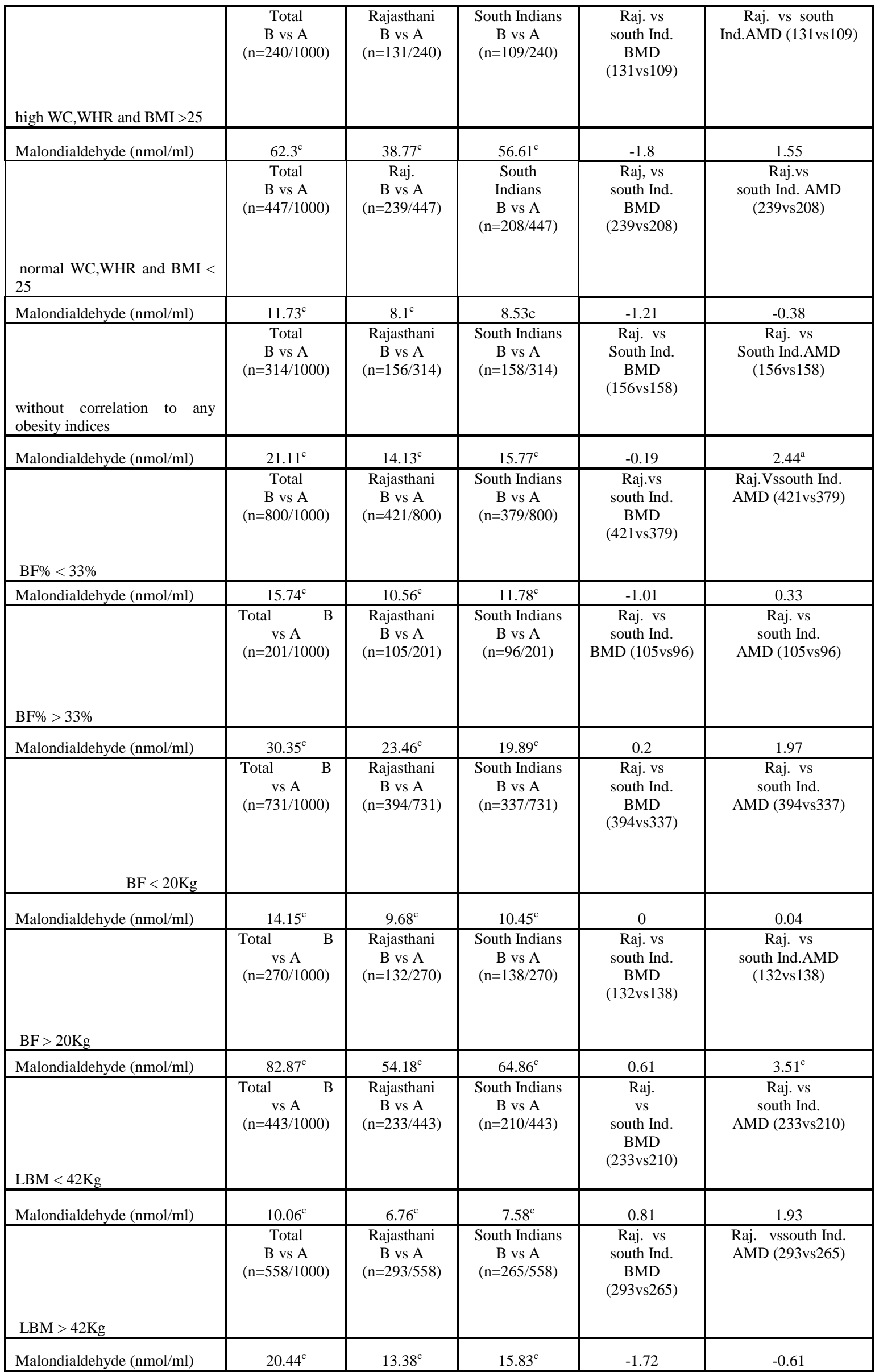




\begin{tabular}{|c|c|c|c|c|c|}
\hline $\mathrm{SFT}<51 \mathrm{~mm}$ & $\begin{array}{c}\text { Total } \\
\text { B vs A } \\
(n=310 / 1000)\end{array}$ & $\begin{array}{c}\text { Rajasthani } \\
\text { B vs A } \\
(n=178 / 310)\end{array}$ & $\begin{array}{c}\text { South Indians } \\
\text { B vs A } \\
(n=132 / 310)\end{array}$ & $\begin{array}{c}\text { Raj. vs } \\
\text { south Ind. } \\
\text { BMD } \\
\text { (178vs132) }\end{array}$ & $\begin{array}{c}\text { Raj. vs } \\
\text { south Ind. AMD } \\
(178 v \mathrm{v} 132)\end{array}$ \\
\hline Malondialdehyde (nmol/ml) & $7.79^{\mathrm{c}}$ & $5.45^{\mathrm{c}}$ & $6.04^{\mathrm{c}}$ & 1.76 & 1.96 \\
\hline $\mathrm{SFT}>51 \mathrm{~mm}$ & $\begin{array}{c}\text { Total } \\
\text { B vs A } \\
(n=691 / 1000)\end{array}$ & $\begin{array}{c}\text { Rajasthani } \\
\text { B vs A } \\
(n=348 / 691)\end{array}$ & $\begin{array}{c}\text { South Indians } \\
\text { B vs A } \\
(n=343 / 691)\end{array}$ & $\begin{array}{l}\text { Raj. vs } \\
\text { south Ind. } \\
\text { BMD } \\
(348 v s 343)\end{array}$ & $\begin{array}{c}\text { Raj. vs } \\
\text { south Ind. AMD } \\
(348 v s 343)\end{array}$ \\
\hline Malondialdehyde (nmol/ml) & $22.14^{\mathrm{c}}$ & $14.89^{\mathrm{c}}$ & $16.45^{\mathrm{c}}$ & -0.39 & 1.33 \\
\hline
\end{tabular}

\section{According to body mass index}

Underweight group $(<18.5)$ had normal MDA. MDA for BMI range of $30-34.99 \mathrm{~kg} / \mathrm{m}^{2}$ was increased. Similar normal range was obtained for BMI range group $\left(18.5-24.9 \mathrm{~kg} / \mathrm{m}^{2}\right)$. Every group of BMI showed significant drop in oxidative status level $(\mathrm{P}<0.001)$. When Rajasthani were compared with south Indians insignificant observation in parameters was seen in underweight\& obese groups; instead MDA was significantly dropped in normal and overweight category.

\section{According to indices of obesity}

Subject who had high waist circumference, waist hip ratio\& BMI > $25 \mathrm{~kg} / \mathrm{m}^{2}$ projected high oxidative stress. When comparison was done with subject having normal waist circumference, waist hip ratio\& BMI $<25 \mathrm{~kg} / \mathrm{m}^{2}$ MDA for overweight and normal group was $3.22 \mathrm{v} / \mathrm{s} 1.64 \mathrm{n}$ moles $/ \mathrm{ml}$ serum. Highly significant effect of fibre diet was observed in all group of indices $(\mathrm{P}<0.001)$. We also compared Rajasthani and south Indian for oxidative stress in BMI >25 along with antioxidant level but there was insignificant correlation.

Effect of fibre diet showed significant drop $(\mathrm{P}<0.001)$ according to Body Fat Percentage and Total body fat, Lean Body Mass and Skin Fold Thickness: Result for respective group were $(\mathrm{P}<0.001)$ and oxidative stress was $1.74 \mathrm{v} / \mathrm{s} 2.62$ in normal \& obese category respectively.

\section{Discussion}

We assessed the prevalence of obesity, their nutritional status of selected obese subjects to evaluate the intervention of developed life style modification program on selected subjects.
The prevalence of obesity is escalating rapidly worldwide (seidell 1999, Shetty 2003) some scientist (hill \& peter 1998, Popkin\& doak 1998) concluded that obesity has already reached epidemic proportion in developed region \& our state might fall into its grip very soon so the coast of obesity to society represent a very important issue $\&$ control of this problem claims priority. Primary pre-requisite for all this is the availability of information about the ground reality of obesity among various population to set goals \& targets to reduce its prevalence. Therefore during present study efforts were made to study current prevalence in two communities.

Life style factors are changing in the two-state attributable to recent economy growth, population growth, change in societal million\& increased urbanization. Consequently, dietary habits of Individuals have changed with decreased in physical activity.

Kaneria et al found the prevalence of obesity in groups \& correlate the effect of fibre diet to be recommended as a remedy for pre-obesity. Life style and eating habits have a direct impact on this burning issue. They are pointer to institute measure to tackle the growing menace of obesity on public health basis. Urgent measures are required for its control. According to study by Tungland $^{[1]}$ there is a generation of free radicals on membrane of cells. Free radicals can be deleterious for membrane as they can cause atherosclerosis, hypertension etc. lipid peroxidation is increased in obesity. Overweight condition can accelerate metabolic pressure \& speed up mechanical load on myocardium. This 
require more oxygen consumption. This result in formation of reactive oxygen species like superoxide, hydroxyl free radicals \& hydrogen peroxide due to accelerated mitochondrial respiration. If antioxidant is enough in body to combat these oxygen species the effects are not clinically manifested, but if antioxidant status is not balanced lipid peroxidation goes on increasing. This lead to degradation of cell due to pressure of body mass degeneration can cause release of tumour, necrosis, factors alpha which also increase peroxidation. Consumption of hyper lipidemicdiets disturbs oxygen metabolism. Fatty acid double bonds are vulnerable to oxidation reactions and thus increase lipid peroxidation ${ }^{3}$. According to van Itallie (2002) plasma concentration of oxidative stress marker was lower $(\mathrm{P}<0.001)$ with good health than those with higher BMI (2.53 $\mathrm{n}$ moles/ $\mathrm{ml}$ serum v/s 4.75). They interpreted that a close association exist between BMI \&oxidative stress.

Present study shows that plasma MDA with normal BMI $(1.8 \pm 0.71)$ after consumption of exclusive fiber diet rich in antioxidant was significant low $(\mathrm{P}<0.001)$ as compared with that of high BMI category of more than $24.9 \mathrm{~kg} / \mathrm{m}^{2}$ $(2.35 \pm 1.02)$. this is also in accordance with study of Reddy K K and others 1997. We observed increase MDA as the BMI group were in high range which is in accordance with studies of Peiris AN and others 1991.Increased peroxidation was a direct consequence of altered functions of membrane of $\mathrm{RBC}$, this result in lowering of antioxidants status \& tissue damage. (Olusi SO) 2002. According to percentage of body fat MDA was $3.14 \mathrm{n}$ mole $/ \mathrm{ml} \mathrm{v} / \mathrm{s} 2.15 \mathrm{n}$ moles $/ \mathrm{ml}$ serum in high \&normal groups. According to lean body mass result was $1.96 \mathrm{n}$ moles/ml v/s $2.66 \mathrm{n}$ moles/ml for normal higher category respectively. Direct relation was seen with skin fold thickness (1.74 \pm 2.62$)$ for normal and high group.

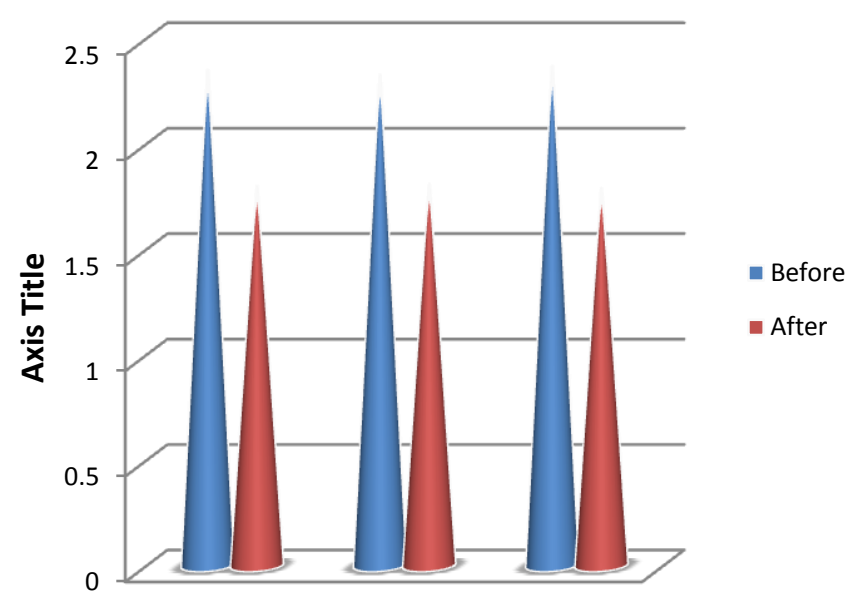

Oxidative Stress in Total, Rajasthani and South Indian Before and after Fiber Diet

Study was in accordance to Qatanani M and Lazar MA [2007] who confirmed that as lipid peroxidation increase oxidative stress also increases which is estimated as high MDA.

Oxidative stress was maximum for obese category. This means that change in low density lipid oxidation is maximum for obese. A significant difference was observed in normal \& high indices category. Normal waist circumference had MDA of $1.64 \mathrm{n}$ moles $/ \mathrm{ml}$ serum as compared to $3.22 \mathrm{n}$ moles $/ \mathrm{ml}$ serum in high abnormal category. There for our study correlate well with the previous result given by Singh et al. sparks JD et al.

\section{Summary}

According to ATP $\|$ guidelines MDA was in normal acceptable range in total / Rajasthani/south Indians subjects. Oxidative stress increase with increase BMI. Dietary effect showed significant drop in all three categories of BMI $(\mathrm{P}<0.001)$.

Highly significant result was observed for overweight\& obese subjects in comparison to normal BMI, after consumption of fiber rich diet exclusively for 30 days. After comparison between two communities, significant result was obtained for high BMI only after diet was taken $(\mathrm{P}<0.001)$ in higher indices category. 


\section{JMSCR Vol||05||Issue||10||Page 29170-29176||October}

\section{Conclusion}

MDA decreased after diet only for abnormal indices group.

Thus, risk of obesity is a consequence of high oxidative stress. This study emphasises on good \&healthy eating habits to prevent from obesity \& weight control. There is urgent need to address this problem \& now is the time to act.

\section{References}

1. B.C.Tungland, and D.Meyer. Nondigestible oligo and polysaccharides, their role in human health. Food Science 2002; 17389.

2. Ferraro S, Perrone-Filardi P, Desiderio A, Betocchi S, D'Alto M, Liguori L, Trimigliozzi $\mathrm{P}$, Turco S, Chiariello $\mathrm{M}$ (1996): Severe obesity: a radionuclide study. Cardiology; 87: 347-353.

3. Fukushige $\mathrm{T}$, Yoshinaga M, Shimago A, Nishi J, Kono Y, Nomura Y, Miyata K, Imamura $\mathbf{M}$, Shibata $T$, Nagashima $M$, Niimura I (2002): Effect of age on overweight.Am J Cardiol; 89: 395-398.

4. Hirsch J, Leibel RL, Mackintosh R, Aguirre A [1991]: Weight change in humans. Am J physiol;261: R1418-R1423

5. K.K. Reddy, R Ramamurty, and Papa Rao. Free radical and antioxidant status in urban and rural Tirupati men, Asia Pacific J Clin nutr 1997;6: 296-311.

6. Kaneria Y, Singh P, Sharma DC (2006): Prevalence of overweight and obesity in relation to socio economic conditions in two different groups of school age children of Udaipur city (Rajasthan). JIACM; 7(2): 133-5.

7. Peiris AN, Thakur RK, Sothmann MS, Gustafson AB, Hennes MI, Wilson CR, Kissebah AH.. Relation of regional fat distribution and obesity. South Med J 1991; 84: 961-5.

8. Qatanani $M$ and Lazar MA [2007]: Mechanism of obesity. Genes Dev;21: 1443-1455.
9. Singh SP, Sikri G, Garg MKBody mass index and obesity; Tailoring cut off for an Asian Indian male population. MJAFI 2008; 64: 350-3.

10. Stephan JL, Richard G, Tom Teerlink Hans V, Reinold OB, Robert J (2000) : Cytosolic triglycerides and oxidative stress in central obesity. Atherosclerosis 148: 1721.

11. Streicher R, Kotzka J,Muller-Wieland D, Siemeister G, Munck M, Avci H, Krane W [1996] :Insulin like growth factor1,Journls of biological chemistry 271:7128-7133.

12. Van Itallie TB.Dietary fiber and obesity: American Journal of Clinical Nutrition 1978; 31: S43-52. 